\title{
The mortality of men in the Rhondda Fach, $1950-1970$
}

\author{
A. L. COChRANE, T. J. L. HALEY, F. MOORE, AND D. HOLE 1 \\ From the MRC Epidemiology Unit, Cardiff, and the ${ }^{1}$ Cancer Intelligence Unit, Glasgow
}

\begin{abstract}
A more detailed analysis of material from the 20-year follow-up of men in the Rhondda Fach confirms the similarity between the Standardised Mortality Ratios (SMRs) of miners and exminers with radiological categories $0,1,2,3$ and $A(120 \cdot 3,116 \cdot 5,119 \cdot 0,115 \cdot 7$, and $120 \cdot 1$ respectively) as well as the difference between these SMRs and that of the non-miners (98.7). The specific death rates show a raised SMR for bronchitis and other respiratory diseases excluding pneumoconiosis for all categories including category 0 , but little difference between those for category 0 and those for simple pneumoconiosis. The SMRs for ischaemic heart disease and other circulatory diseases for categories A, B and C combined are lower than those for simple pneumoconiosis and category 0 (84.2 and 85.0 , compared with 109.8 and 121.8 for simple pneumoconiosis, and 117.5 and 114.6 for category 0). Fortunately the SMR for leukaemia is low. A comparison between the survival rates of men aged 55-64 in Leigh, Lancashire and those in the Rhondda Fach suggests that nonminers in the two areas have similar survival rates while the survival rates for category 0 and simple pneumoconiosis are lower in the Rhondda Fach.
\end{abstract}

In 1973 one of us (ALC) published the preliminary results of a 20-year follow-up of the men living in the Rhondda Fach who had been examined in 1950-51 (Cochrane et al., 1952). The interval has been used to re-check our data and continue the analysis. This paper, in addition to presenting the previous results slightly altered by the checking, adds mortality rates by specific cause of death, a separate analysis of the fate of miners in 1950-51 compared with ex-miners in the Rhondda Fach in 1950-51, and a comparison with the results of the Leigh survey (Cochrane and Moore, 1978).

\section{Materials and methods}

The population has previously been described on several occasions (Cochrane et al., 1952; Cochrane et al., 1964; Cochrane, 1973). It consists essentially of a mining community, the Rhondda Fach, first examined in 1950-51 and followed up for 20 years. The population used here differs from that used by Cochrane et al. in 1964 by the addition to the

Received for publication 1 March 1978

Accepted for publication 4 July 1978 radiographed population of 32 miners and exminers, for whom further evidence of their radiological categories became available. The population also differs in many trivial ways from that described by Cochrane in 1973 because of the checks carried out and modifications introduced. These included: (a) an intensive search for duplicates; (b) a comparison of dates of birth on death certificates and on the cards at the time of the survey; (c) a check on all the data transcribed from the Registrar General's Annual Reviews for the purpose of calculating expected deaths. In addition, a detailed comparison of the dates on the individual radiographs and the dates of death led to the exclusion of a few deaths as they had occurred shortly after the 20-year interval. We also checked the methods of making the specific causes of death comparable in spite of the changes in the International Classification of Diseases (ICD) categories. We decided that it was unrealistic to continue to omit deaths caused by colliery accidents in a 20-year follow-up as we had done previously. The use of Carpenter's technique would involve assuming the men were still alive. There were other reasons for doing this: it was difficult to identify colliery accidents from the ICD classification; even when this was done as accurately as possible, 
the difference made by their omission or addition to survival rates and SMRs was slight. (Of course, we are not suggesting that they are unimportant as a preventable cause of death.) This means that the SMRs in this paper are not directly comparable with those published by Cochrane et al. (1964).

The expected numbers of deaths used in the determination of SMRs were calculated from the Registrar General's annual Statistical Reviews of England and Wales. As the present study is protracted the changing age structure of the population must be taken into account in the calculation of expected numbers of deaths: after a year, a man initially aged 20 will be subject to the death rate affecting a 21-year-old. The Registrar General gives death rates for five-year age groups only, and thus it is necessary to estimate the rates affecting intermediate ages. A weighted average of corresponding five-year age group values is used; details may be found in Carpenter et al. (1956) and Cochrane et al. (1964).

\section{Results}

SURVIVAL RATES

Tables 1-4 are the corrected versions of those

Table 1 The populations of Rhondda Fach men available for analysis, related to the defined populations in 1950-51 by age and occupation

\begin{tabular}{|c|c|c|c|c|c|c|c|}
\hline \multirow[t]{2}{*}{ Age group (yr) } & \multicolumn{3}{|l|}{ Non-miners } & \multicolumn{4}{|c|}{ Miners and ex-miners } \\
\hline & $\begin{array}{l}\text { Defined } \\
\text { population } \\
1950-51\end{array}$ & No. not traced & $\begin{array}{l}\text { No. available } \\
\text { for analysis }\end{array}$ & $\begin{array}{l}\text { Defined } \\
\text { population } \\
1950-51\end{array}$ & $\begin{array}{l}\text { Radiographic } \\
\text { status not } \\
\text { available }\end{array}$ & No. not traced & $\begin{array}{l}\text { No. available } \\
\text { for analysis }\end{array}$ \\
\hline $\begin{array}{l}20-24 \\
25-34 \\
35-44 \\
45-54 \\
55-64 \\
65-74 \\
75+\end{array}$ & $\begin{array}{r}492 \\
738 \\
447 \\
223 \\
148 \\
62 \\
32\end{array}$ & $\begin{array}{l}0 \\
1 \\
1 \\
1 \\
1 \\
0 \\
0\end{array}$ & $\begin{array}{r}492 \\
737 \\
446 \\
222 \\
147 \\
62 \\
32\end{array}$ & $\begin{array}{r}325 \\
1147 \\
1346 \\
1337 \\
1168 \\
766 \\
295\end{array}$ & $\begin{array}{r}1 \\
4 \\
6 \\
6 \\
25 \\
54 \\
72\end{array}$ & $\begin{array}{l}0 \\
2 \\
0 \\
0 \\
0 \\
2 \\
0\end{array}$ & $\begin{array}{r}324 \\
1141 \\
1340 \\
1331 \\
1143 \\
710 \\
223\end{array}$ \\
\hline Total & 2142 & 4 & 2138 & 6384 & 168 & 4 & 6212 \\
\hline
\end{tabular}

Table 2 Miners and ex-miners by age group and radiological status in 1950-51

\begin{tabular}{|c|c|c|c|c|c|c|c|}
\hline \multirow[t]{2}{*}{ Age group (yr) } & \multicolumn{6}{|c|}{ Radiological category } & \multirow[t]{2}{*}{ Total } \\
\hline & 0 & 1 & 2 & 3 & $\boldsymbol{A}$ & $B C$ & \\
\hline $\begin{array}{l}20-24 \\
25-34 \\
35-44 \\
45-54 \\
55-64 \\
65-74 \\
75+\end{array}$ & $\begin{array}{l}278 \\
720 \\
668 \\
696 \\
563 \\
328 \\
123\end{array}$ & $\begin{array}{r}25 \\
147 \\
157 \\
187 \\
165 \\
99 \\
29\end{array}$ & $\begin{array}{r}17 \\
119 \\
174 \\
128 \\
105 \\
70 \\
13\end{array}$ & $\begin{array}{r}1 \\
82 \\
120 \\
70 \\
46 \\
25 \\
4\end{array}$ & $\begin{array}{r}2 \\
47 \\
89 \\
98 \\
78 \\
59 \\
13\end{array}$ & $\begin{array}{r}1 \\
26 \\
132 \\
152 \\
186 \\
129 \\
41\end{array}$ & $\begin{array}{r}324 \\
1141 \\
1340 \\
1331 \\
1143 \\
710 \\
223\end{array}$ \\
\hline Total & 3376 & 809 & 626 & 348 & 386 & 667 & 6212 \\
\hline
\end{tabular}

Table 3 Numbers of deaths of all men in 20 years, by age, occupation and radiological category

\begin{tabular}{|c|c|c|c|c|c|c|c|}
\hline \multirow[t]{3}{*}{ Age group (yr) } & \multirow[t]{3}{*}{ Non-miners } & \multicolumn{6}{|c|}{ Miners and ex-miners } \\
\hline & & \multicolumn{6}{|c|}{ Radiological category } \\
\hline & & 0 & 1 & 2 & 3 & $\boldsymbol{A}$ & $B C$ \\
\hline $\begin{array}{l}20-24 \\
25-34 \\
35-44 \\
45-54 \\
55-64 \\
65-74 \\
(*) \\
75+ \\
(* *)\end{array}$ & $\begin{array}{c}14 \\
48 \\
78 \\
78 \\
98 \\
55 \\
(50) \\
32 \\
(27)\end{array}$ & $\begin{array}{r}13 \\
40 \\
123 \\
340 \\
435 \\
304 \\
(263) \\
122 \\
(101)\end{array}$ & $\begin{array}{r}0 \\
7 \\
38 \\
88 \\
122 \\
91 \\
(81) \\
29 \\
(27)\end{array}$ & $\begin{array}{c}0 \\
7 \\
41 \\
57 \\
80 \\
65 \\
(59) \\
13 \\
(11)\end{array}$ & $\begin{array}{c}0 \\
9 \\
26 \\
24 \\
30 \\
25 \\
(22) \\
4 \\
(4)\end{array}$ & $\begin{array}{c}0 \\
2 \\
22 \\
45 \\
66 \\
54 \\
(45) \\
13 \\
(10)\end{array}$ & $\begin{array}{r}0 \\
5 \\
69 \\
108 \\
163 \\
122 \\
(113) \\
41 \\
(38)\end{array}$ \\
\hline
\end{tabular}

(*)Number of deaths in $15 \mathrm{yr}$ 
Table 4 Percentage of the male population by age and radiological status in 1950-51 surviving 20 years

\begin{tabular}{|c|c|c|c|c|c|c|c|}
\hline \multirow[t]{3}{*}{ Age group (yr) } & \multirow[t]{3}{*}{ Non-miners } & \multicolumn{6}{|c|}{ Miners and ex-miners } \\
\hline & & \multicolumn{6}{|c|}{ Radiological category } \\
\hline & & 0 & 1 & 2 & 3 & $A$ & $B C$ \\
\hline $\begin{array}{l}20-24 \\
25-34 \\
35-44 \\
45-54 \\
55-64 \\
65-74^{*} \\
75+* *\end{array}$ & $\begin{array}{l}97 \cdot 2 \\
93 \cdot 5 \\
82 \cdot 5 \\
64 \cdot 9 \\
33 \cdot 3 \\
19 \cdot 4 \\
15 \cdot 6\end{array}$ & $\begin{array}{l}95 \cdot 3 \\
94 \cdot 4 \\
81 \cdot 6 \\
51 \cdot 1 \\
22 \cdot 7 \\
19 \cdot 8 \\
17 \cdot 9\end{array}$ & $\begin{array}{c}(100.0) \\
95.2 \\
75.8 \\
52.9 \\
26.1 \\
18.2 \\
6.9\end{array}$ & $\begin{array}{c}(100.0) \\
94.1 \\
75.9 \\
55.5 \\
23.8 \\
15.7 \\
(15.4)\end{array}$ & $\begin{array}{c}(100 \cdot 0) \\
89.0 \\
78.3 \\
65 \cdot 7 \\
34.8 \\
12.0 \\
(0.0)\end{array}$ & $\begin{array}{c}(100.0) \\
97.6 \\
75.3 \\
54 \cdot 1 \\
15.4 \\
23.7 \\
(23 \cdot 1)\end{array}$ & $\begin{array}{r}(100.0) \\
80.8 \\
47.8 \\
28.9 \\
12.4 \\
12.4 \\
7.3\end{array}$ \\
\hline
\end{tabular}

* Percentage surviving 15 yr

* * Percentage surviving 10 yr

Numbers in parentheses indicate less than 25 subjects at risk

already published. In comparison with the publication in 1973 (Cochrane) we have added the 20-24 age group. The defined population in 1950-51 of non-miners aged 25 or over has been reduced by one and that of the miners and ex-miners by three. The number of the latter untraced in 1970 fell by one. The number of miners and ex-miners about whom there was no evidence regarding the category of pneumoconiosis also fell by one. We consider that the general coverage is satisfactory (Table 1), although there were relatively too many miners and ex-miners in the higher age groups whose radiographic status was unknown. A few maverick points must be expected in a population broken down into 49 cells (Table 4). Here the most obvious one, although there are others, is the very low survival rate for category $A$ in age group 55-64, followed by a high value in the 65-74 age group. Another oddity is the relatively low survival rate of those aged 35-44 with simple pneumoconiosis. This can hardly mean that the younger the man in whom pneumoconiosis appears, the worse the prognosis, because the survival rates in the age group 25-34 are much better. The 35-44 age group is possibly a heavy smoking cohort induced by the war (Campbell, personal communication, 1969). A more conventional approach to survival is illustrated in Table 5, which gives the SMRs for the age range 25-74*. The similarity of the SMRs for categories $0,1,2,3$ and $A$ is striking, as is their difference from that of the non-miners, and from categories B and C. The higher SMR for category A published in Cochrane (1976), was for men aged 25-64. We consider that this age range gives too much weight to the maverick point.

SPECIFIC MORTALITY

Table 6 shows the SMRs for the age group 25-74

*SMRs are also available from the MRC Epidemiology Unit for the age range $20-64$, together with all subsequent SMRs.
Table 5 Standardised mortality ratios for males by occupation and radiological status in 1950-51 for the age group $25-74$

\begin{tabular}{|c|c|c|c|}
\hline \multirow[t]{2}{*}{ Group } & \multicolumn{3}{|l|}{ SMR 25-74 } \\
\hline & Observed deaths & $S M R$ & $S E$ \\
\hline $\begin{array}{l}\text { Non-miners } \\
\text { Miners and ex-miners }\end{array}$ & 357 & $98 \cdot 7$ & $5 \cdot 2$ \\
\hline $\begin{array}{l}\text { Category 0 } \\
\text { Category } 1 \\
\text { Category } 2 \\
\text { Category 3 } \\
\text { Category A } \\
\text { Category BC }\end{array}$ & $\begin{array}{r}1242 \\
346 \\
251 \\
114 \\
189 \\
467\end{array}$ & $\begin{array}{l}120 \cdot 3 \\
116 \cdot 5 \\
119 \cdot 0 \\
115 \cdot 7 \\
120 \cdot 1 \\
195 \cdot 1\end{array}$ & $\begin{array}{r}3 \cdot 4 \\
6 \cdot 3 \\
7 \cdot 5 \\
10 \cdot 8 \\
8 \cdot 7 \\
9 \cdot 0\end{array}$ \\
\hline
\end{tabular}

for the main specific disease categories. The main points are as follows. First, miners and ex-miners have higher SMRs for respiratory disease compared with non-miners, without any evidence of increasing SMR with increasing category of simple pneumoconiosis. Second, for carcinoma of the lung the SMRs are equally low for non-miners and for miners and ex-miners. Third, the results for carcinoma of the stomach can be described only as bizarre, while 'accidents' show the expected raised SMR among miners and ex-miners. The higher value for those with simple pneumoconiosis presumably reflects the higher percentage of men on the coal face. Table 7 gives the age-specific case fatality rates for deaths attributable to pneumoconiosis as this type of death certification is not suitable for analysis by SMRs. It shows the expected increase of case fatality rate with category. We also examined the SMRs for the remainder of the specific disease categories to ensure that nothing important had been overlooked.

COMPARISON BETWEEN MINERS AND EXMINERS

Table 8 shows the SMRs for all causes of deaths 
Table 6 Standardised mortality ratios for specific causes of death by occupation and radiological status for age group 25-74

\begin{tabular}{|c|c|c|c|c|c|c|c|c|}
\hline \multirow[t]{2}{*}{ Group } & \multicolumn{2}{|l|}{ Bronchitis } & \multicolumn{2}{|c|}{ Other* respiratory disease } & \multicolumn{2}{|c|}{ Ischaemic heart disease } & \multicolumn{2}{|c|}{ Other circulatory disease } \\
\hline & $\begin{array}{l}\text { Observed } \\
\text { deaths }\end{array}$ & $S M R$ & $\begin{array}{l}\text { Observed } \\
\text { deaths }\end{array}$ & $S M R$ & $\begin{array}{l}\text { Observed } \\
\text { deaths }\end{array}$ & $S M R$ & $\begin{array}{l}\text { Observed } \\
\text { deaths }\end{array}$ & $S M R$ \\
\hline $\begin{array}{l}\text { Non-miners } \\
\text { Cat. } 0 \\
\text { Cat. } 1,2,3 \\
\text { Cat. A, B, C }\end{array}$ & $\begin{array}{r}21 \\
169 \\
102 \\
59\end{array}$ & $\begin{array}{r}80 \cdot 2 \\
209 \cdot 2 \\
214 \cdot 3 \\
188 \cdot 5\end{array}$ & $\begin{array}{l}15 \\
90 \\
51 \\
40\end{array}$ & $\begin{array}{r}62 \cdot 2 \\
121 \cdot 6 \\
119 \cdot 2 \\
135 \cdot 6\end{array}$ & $\begin{array}{r}114 \\
345 \\
190 \\
95\end{array}$ & $\begin{array}{r}111 \cdot 3 \\
117 \cdot 5 \\
109 \cdot 8 \\
84 \cdot 2\end{array}$ & $\begin{array}{r}73 \\
251 \\
156 \\
75\end{array}$ & $\begin{array}{r}104 \cdot 3 \\
114 \cdot 6 \\
121 \cdot 8 \\
85 \cdot 0\end{array}$ \\
\hline
\end{tabular}

*Excluding pneumoconiosis

of those who were working miners in 1950-51 with those who were ex-miners, by radiographic category. The differences are considerable in categories 2 and 3, the SMRs being lower for the working miners.

\section{COMPARISON WITH MEN IN LEIGH,}

LANCASHIRE

Table 9 shows the remarkable similarities and dissimilarities between the two areas. On the one hand, the survival rates of the non-miners in the two areas are reasonably similar, and in both areas the rates for category 0 and categories 1,2 and 3 are similar. On the other hand, the rates for categories $0,1,2$ and 3 are similar to those for the non-miners in Leigh but different in the Rhondda Fach, and the survival rates for the same categories in the Rhondda are much lower than those in Leigh. The rates for categories A, B and C are not comparable in the two areas because of the absence of $C$ shadows in Leigh and because of the small numbers. Unfortunately this comparison can be made only for this one age group (55-64).

\section{Discussion}

\section{CRITICISMS}

Campbell et al. (1973) argued in the first place that the results might have been different if the ILO International Classification of Radiographs of the Pneumoconioses (International Labour Office, 1970) had been used rather than the ILO classification of 1959. This we agree is true. We have given Campbell all the Leigh radiographs, in the hope of clarifying this point. At the same time, we are not convinced that the 'irregular marking' category is of value in classifying coal miners' radiographs. The only attempt to evaluate this on unselected populations of living miners was by Waters et al. (1974) using the old 'punctiform' classification. They failed to demonstrate any relationship with expectation of life. There were, it is agreed, only 19 men with punctiform shadows, but they were part of a random sample of a population. We are, of course, aware that others find the new classification of value (Lyons et al., 1974). Ryder et al. (1970) considered that the punctiform classification was a good indicator of irregular markings. We do not agree that the problem could be solved by examining the lungs of those Rhondda miners who died, as we would be unable to compare the findings with data from those who had not died. Their remarks about disability will be discussed in a later paper; this one is restricted to mortality.

The main point stressed by Curry (1973) was the argument that miners with progressive massive fibrosis (PMF) left mining, sacrificing their wealth to save their health and prolong their lives. $\mathrm{He}$ is probably correct in thinking that those who leave mining are, on average, more disabled than those who remain in that occupation, but incorrect in thinking that leaving mining will reduce the rate of progression of A shadows. All the evidence suggests that the rate of progression of $A$ shadows is independent of leaving mining (Davies et al., 1949; Cochrane and Carpenter, 1956; Cochrane et al., 1961b). Apart from this, he concentrates his attack on the maverick values for A shadows in the age group 55-64. This is of some interest as, on the basis of the literature, we would have expected a lower survival rate in the younger As, because the evidence suggests that $A$ shadows increase in area in this group and thus progress to category $B$ and $C$ faster than they do in older men (Cochrane et al., 1961b). We were, therefore, surprised by this high survival value in the younger men and the low value in the 55-64 age group. If one assumes an expected SMR of 120 (Table 5) one finds that there are 12 excess deaths in the 55-64 age group. In the 65-74 age group there appear to be 17 too few. In the 45-54 age group there are three excess deaths. We have also tried to find out the specific cause of the excess deaths by comparing expected and observed deaths for each cause in the 55-64 age group for category $\mathrm{A}$, with the two neighbouring age groups for category A, and the 55-64 age group for cate- 


\begin{tabular}{|c|c|c|c|c|c|c|c|}
\hline \multicolumn{2}{|c|}{ Carcinoma of lung } & \multicolumn{2}{|c|}{ Carcinoma of stomach } & \multicolumn{2}{|c|}{ Other malignant disease } & \multicolumn{2}{|c|}{ Accidents and other violence } \\
\hline $\begin{array}{l}\text { Observed } \\
\text { deaths }\end{array}$ & $S M R$ & $\begin{array}{l}\text { Observed } \\
\text { deaths }\end{array}$ & $S M R$ & $\begin{array}{l}\text { Observed } \\
\text { deaths }\end{array}$ & $S M R$ & $\begin{array}{l}\text { Observed } \\
\text { deaths }\end{array}$ & $S M R$ \\
\hline 21 & $65 \cdot 6$ & 13 & $113 \cdot 0$ & 31 & $80 \cdot 9$ & 12 & $67 \cdot 4$ \\
\hline 57 & $69 \cdot 5$ & 52 & 159.5 & 81 & $76 \cdot 4$ & 45 & $124 \cdot 7$ \\
\hline 33 & 67.6 & 21 & $108 \cdot 2$ & 38 & $61 \cdot 0$ & 35 & $167 \cdot 5$ \\
\hline 23 & $80 \cdot 1$ & 23 & 184.0 & 29 & $72 \cdot 3$ & 7 & $59 \cdot 3$ \\
\hline
\end{tabular}

Table 7 Age-specific death rates in 20 years for miners and ex-miners by original radiological status

\begin{tabular}{|c|c|c|c|c|c|c|c|c|c|}
\hline \multirow{3}{*}{$\begin{array}{l}\text { Radiological } \\
\text { category }\end{array}$} & \multicolumn{9}{|c|}{ Age group } \\
\hline & \multicolumn{3}{|l|}{$25-44$} & \multicolumn{3}{|c|}{$45-64$} & \multicolumn{3}{|c|}{$65-74$} \\
\hline & No. & Deaths & $\%$ & No. & Deaths & $\%$ & No. & Deaths & $\%$ \\
\hline 0 & 1388 & 2 & $0 \cdot 1$ & 1259 & 5 & 0.4 & 328 & 5 & 1.5 \\
\hline 1 & 304 & 2 & 0.7 & 352 & 1 & 0.3 & 99 & 1 & 1.0 \\
\hline 2 & 293 & 7 & $2 \cdot 4$ & 233 & 6 & $2 \cdot 6$ & 70 & 2 & 2.9 \\
\hline 3 & 202 & 1 & 0.5 & 116 & 8 & 6.9 & 25 & 1 & 4.0 \\
\hline A & 136 & 3 & $2 \cdot 2$ & 176 & 23 & $13 \cdot 1$ & 59 & 7 & 11.9 \\
\hline BC & 158 & 49 & $31 \cdot 0$ & 338 & 138 & $40 \cdot 8$ & 129 & 54 & 41.9 \\
\hline
\end{tabular}

Table 8 Standardised mortality ratios for men aged 25-74 by occupation and radiological status

\begin{tabular}{|c|c|c|c|c|c|c|}
\hline \multirow{2}{*}{$\begin{array}{l}\text { Radiological } \\
\text { category }\end{array}$} & \multicolumn{3}{|l|}{ Miners } & \multicolumn{3}{|l|}{ Ex-miners } \\
\hline & Observed deaths & Expected deaths & $S M R$ & Observed deaths & Expected deaths & $S M R$ \\
\hline $\begin{array}{l}0 \\
1 \\
2 \\
3 \\
\text { A } \\
\text { BC }\end{array}$ & $\begin{array}{r}500 \\
146 \\
84 \\
44 \\
50 \\
66\end{array}$ & $\begin{array}{r}426.0 \\
120 \cdot 6 \\
77 \cdot 0 \\
41 \cdot 1 \\
43 \cdot 4 \\
31 \cdot 4\end{array}$ & $\begin{array}{l}117 \cdot 3 \\
121 \cdot 1 \\
109 \cdot 0 \\
107 \cdot 1 \\
115 \cdot 2 \\
210 \cdot 2\end{array}$ & $\begin{array}{r}742 \\
200 \\
167 \\
70 \\
139 \\
401\end{array}$ & $\begin{array}{r}606 \cdot 3 \\
176 \cdot 5 \\
134 \cdot 0 \\
57 \cdot 4 \\
113 \cdot 9 \\
208 \cdot 0\end{array}$ & $\begin{array}{l}122.4 \\
113.4 \\
124.6 \\
121.9 \\
122.0 \\
192 \cdot 8\end{array}$ \\
\hline Non-miners & 357 & $361 \cdot 8$ & $98 \cdot 7$ & & & \\
\hline
\end{tabular}

Table 9 Twenty-year survival rates for men aged 55-64 in two mining communities

\begin{tabular}{|c|c|c|c|c|c|c|}
\hline \multirow[t]{3}{*}{ Subject group } & \multicolumn{4}{|c|}{ Leigh } & \multicolumn{2}{|c|}{ Rhondda Fach } \\
\hline & \multicolumn{2}{|c|}{ Total sample } & \multicolumn{2}{|c|}{ 'Purified' sample* } & \multirow[b]{2}{*}{ No. } & \multirow[b]{2}{*}{$\begin{array}{l}\% \\
\text { surviving }\end{array}$} \\
\hline & No. & $\begin{array}{l}\% \\
\text { surviving }\end{array}$ & No. & $\begin{array}{l}\% \\
\text { surviving }\end{array}$ & & \\
\hline $\begin{array}{l}\text { Non-miners } \\
\text { Miners and ex-miners }\end{array}$ & 84 & $34 \cdot 5$ & 49 & $32 \cdot 7$ & 148 & 33.3 \\
\hline $\begin{array}{l}\text { Radiological category } 0 \\
\text { Radiological categories } 1,2,3 \\
\text { Radiological categories A, B, C }\end{array}$ & $\begin{array}{r}101 \\
21 \\
10\end{array}$ & $\begin{array}{l}29 \cdot 7 \\
33 \cdot 3 \\
20 \cdot 0\end{array}$ & $\begin{array}{r}64 \\
17 \\
4\end{array}$ & $\begin{array}{l}32 \cdot 8 \\
29 \cdot 4 \\
25 \cdot 0\end{array}$ & $\begin{array}{l}563 \\
316 \\
264\end{array}$ & $\begin{array}{l}22 \cdot 7 \\
26 \cdot 6 \\
12 \cdot 9\end{array}$ \\
\hline
\end{tabular}

*Containing only those who were not exposed to any other industrial respiratory hazards

gory 3. Both approaches are unsatisfactory but they suggested that the main cause of the excess deaths was carcinoma of the stomach! We then considered the hypothesis that the radiograph readers in 1950-51 (of whom ALC was one) had misread a metastasis in the lung from a cancer of the stomach as an $\mathbf{A}$ shadow, but there were no deaths from cancer of the stomach in this age-radiographic category 
group within three years of the 1950-51 survey. We feel that this, from the point of view of the epidemiology of pneumoconiosis, might well be forgotten, unless there is a link between the aetiology of cancer of the stomach and PMF.

Davies, in 1973, suggested that there might be an inverse relationship between category and the prevalence of bronchitis. There is no epidemiological evidence of this, but Davies demanded careful postmortem evidence. The underlying idea that excessive mucus production protects against simple pneumoconiosis has surely been rendered improbable by Jacobsen et al. (1977) and Muir et al. (1977) since then.

A Lancet Editorial (1974), in addition to supporting Curry, states that 'Cochrane's claim that category A does not shorten life conflicts with a great deal of clinical experience'. No reference was given to the clinicians concerned. Whatever the final explanation may be it is, surely, incorrect to treat unreferenced clinical opinion as the equal, apparently, of epidemiological data. Is this the last cry of a clinical Canute trying to stem the advancing waves of quantitative medicine? We are sorry that it appeared in the Lancet.

\section{CURRENT FINDINGS}

Our detailed check has failed to upset our preliminary finding that miners and ex-miners with simple pneumoconiosis survive as well as those with category $\mathbf{0}$. This is not surprising as it is confirmed by other surveys (Higgins et al., 1968; Ortmeyer et al., 1974; Cochrane and Moore, 1978) and we know of no evidence to the contrary. It seems very unlikely that a combination of a lower survival rate of simple pneumoconiosis could be concealed by an odd combination of selection into and within coal-mining and selective migration of ex-miners out of the defined areas before the cross-sectional surveys in four such different regions (Rhondda Fach, Leigh, Staveley, and the Appalachians, USA).

Our preliminary suggestion that the survival rate of those with category $\mathbf{A}$ was similar to that of category 0 is fully confirmed by the SMR for those aged 25-74. It is also identical with our previous conclusion (Cochrane et al., 1961a). We still find this surprising, as some men with A shadows are known to progress fairly rapidly to death. The simplest explanation would be a compensating low mortality for some other disease. The low SMRs for A shadows for ischaemic heart disease (86.7) and for other circulatory diseases (100.9), compared with those for simple pneumoconiosis $(109 \cdot 8)$ and $(121 \cdot 8)$ suggest that this may account for part of the difference. Possibly the clinical
Canute was failing to distinguish between specific mortality and mortality from all causes!

As regards specific mortality, our findings about cancer of the lung do not give any support to the idea of coal dust exposure having the protective effect that others have suggested (Goldman, 1965). We have also analysed this finding by individual radiological category without altering our opinion. The SMRs for cancer of the stomach are admittedly bizarre, but they give no support to the suggestion (Matolo et al., 1972) that exposure to dust is an aetiological factor. The difference between the SMRs of non-miners and men in category 0 is large, but there is little or no suggestion of death rates being related to category of pneumoconiosis (Table 6) except, of course, when one is dealing with pneumoconiosis as a specific cause of death. We have also examined the SMR for leukaemia. One of us (ALC) was, in the fifties, innocently responsible for the increased radiation to which this population was exposed. We are happy to report that, in the age range $25-74,8.7$ deaths from leukaemia were expected, but only five were observed.

The differences between the SMRs for those who were miners in 1950-51 and those who were ex-miners are of interest. Unfortunately, we do not know why miners leave mining. In our population, some left because they were certified as having pneumoconiosis before 1948; some probably left because they didn't like the life; others left because they were disabled: it is probably the latter group that causes the difference in SMR between those who were miners and ex-miners in 1950-51. Although the differences are somewhat smaller than we expected, they do suggest that a definite bias is introduced by using follow-up studies of working miners compared with those of communities containing both miners and ex-miners.

The real unsolved mystery about the Rhondda Fach is apparent in Table 9. The survival rates for the non-miners are similar in the two areas but those for miners and ex-miners, when standardised for category, show remarkable differences. It is clearly of the greatest importance to establish which of these represents the norm and which the exception. Additional information about this will be available when (and if) we complete the 20-year follow-up at Staveley. We believe, on the basis of the nine-year follow-up (Higgins et al., 1968) that it will be similar to that of Leigh, and we are therefore concentrating on hypotheses which might explain the aberrant position of the Rhondda Fach. The only hypothesis put forward so far to explain this (Cochrane and Higgins, 1961) is that the high migration rates out of the Rhondda in the 1920 s and 1930s may have led to a residual population 
with lower average forced expiratory volumes and higher mortality rates than in other areas. We hope to investigate this further.

\section{References}

Campbell, H., Lyons, J. P., Gough, J., and Ryder, R. (1973). Coalworkers' pneumoconiosis. British Medical Journal, 3, 351 .

Carpenter, R. G., Cochrane, A. L., Clarke, W. G., Jonathan, G., and Moore, F. (1956). Death rates of miners and ex-miners with and without coalworkers' pneumoconiosis in South Wales. British Journal of Industrial Medicine, 13, 102-109.

Cochrane, A. L. (1973). Relation between radiographic categories of coalworkers' pneumoconiosis and expectation of life. British Medical Journal, 2, 532-534.

Cochrane, A. L. (1976). An epidemiologist's view of the relationship between simple pneumoconiosis and morbidity and mortality. Proceedings of the Royal Society of Medicine, 69, 12-14.

Cochrane, A. L., and Carpenter, R. G. (1956). Factors influencing the radiological progression rate of progressive massive fibrosis. British Journal of Industrial Medicine, 13, 177-183.

Cochrane, A. L., and Higgins, I. T. T. (1961). Pulmonary ventilatory functions of coalminers in various areas in relation to the $x$-ray category of pneumoconiosis. British Journal of Preventive and Social Medicine, 15, 1-11.

Cochrane, A. L., and Moore, F. (1978). Preliminary results of a twenty-year follow-up of a random sample of an industrial town. British Medical Journal, 1, 411-412.

Cochrane, A. L., Cox, J. G., and Jarman, T. F. (1952). Pulmonary tuberculosis in the Rhondda Fach. British Medical Journal, 2, 843-853.

Cochrane, A. L., Moore, F., and Thomas J. (1961a). The prognostic value of radiological classification in cases of progressive massive fibrosis. Tubercle, 42, 64-71.

Cochrane, A. L., Moore, F., and Thomas, J. (1961b). The radiographic progression of progressive massive fibrosis. Tubercle, 42, 72-77.

Cochrane, A. L., Carpenter, R. G., Moore, F., and Thomas, J. (1964). The mortality of miners and ex-miners in the Rhondda Fach. British Journal of Industrial Medicine, 21, 38-45.
Curry, B. (1973). Survival in coalworkers' pneumoconiosis. British Medical Journal, 3, 633-634.

Davies, D. (1973). Disability, survival, and coalworkers' pneumoconiosis. British Medical Journal, 2, 773-774.

Davies, I., Fletcher, C. M., Mann, K. J., and Stewart, A. (1949). Radiological progression in coalminers' pneumoconiosis. In Proceedings of the Ninth International Congress on Industrial Medicine, London, 13-17 September, 1948 , pp. 773-778. John Wright: Bristol.

Editorial. (1974). The miners: a special case? Lancet, 1, 81-82

Goldman, K. P. (1965). Mortality of coalminers from carcinoma of the lung. British Journal of Industrial Medicine, 22, 72-77.

Higgins, I. T. T., Gilson, J. C., Ferris, B. G., Waters, W. E., Campbell, H., and Higgins, M. W. (1968). IV. Chronic respiratory disease in an industrial town: a nine-year follow-up study. Preliminary report. American Journal of Public Health, 58, 1667-1676.

International Labour Office (1959). International Classification of Radiographs of the Pneumoconioses. Occupational Safety and Health Series No. 9. ILO: Geneva.

International Labour Office (1970). International Classification of Radiographs of the Pneumoconioses. Occupational Safety and Health Series No. 22. ILO: Geneva.

Jacobsen, M., Burns, J., and Attfield, M. D. (1977). Smoking and coalworkers' simple pneumoconiosis. In Inhaled Particles IV, Part 2, pp. 759-771. Edited by W. H. Walton. Pergamon Press: Oxford.

Lyons, J. P., Ryder, R. C., Campbell, H., Clarke, W. G., and Gough, J. (1974). Significance of irregular opacities in the radiology of coalworkers' pneumoconiosis. British Journal of Industrial Medicine, 31, 36-44.

Matolo, N. M., Gorishek, W. M., and Moslander, V. (1972). Coal mining and cancer of the stomach. Rocky Mountains Medical Journal, 69, 44-49.

Muir, D. C. F., Burns, J., Jacobsen, M., and Walton, W. H. (1977). Pneumoconiosis and chronic bronchitis. British Medical Journal, 2, 424-427.

Ortmeyer, C. E., Costello, J., Morgan, W. K. C., Sweker, S., and Peterson, M. (1974). The mortality of Appalachian coal miners, 1963 to 1971. Archives of Environmental Health, 29, 67-72.

Ryder, R., Lyons, J. P., Campbell, H., and Gough, J. (1970). Emphysema in coal workers' pneumoconiosis. British Medical Journal, 3, 481-487.

Waters, W. E., Cochrane, A. L., and Moore, F. (1974) Mortality in punctiform type of coalworkers' pneumoconiosis. British Journal of Industrial Medicine, 31, 196-200. 


\section{Appendix}

Groupings of causes of death from Registrar General used for SMRs

\begin{tabular}{|c|c|c|}
\hline \multirow[t]{2}{*}{ Cause } & \multicolumn{2}{|l|}{ Required categories } \\
\hline & $\begin{array}{l}\text { Before } 1968 \\
\text { (6th and } 7 \text { th Revisions) }\end{array}$ & $\begin{array}{l}1968 \text { onwards } \\
\text { (8th Revision) }\end{array}$ \\
\hline $\begin{array}{l}\text { (a) Total mortality } \\
\text { (b) Lung cancer } \\
\text { (c) Stomach cancer } \\
\text { (d) Leukaemia } \\
\text { (e) Other malignant neoplasms } \\
\text { (f) Chronic bronchitis } \\
\text { (g) Pneumoconiosis } \\
\text { (h) Other respiratory diseases } \\
\text { (i) Ischaemic heart disease } \\
\text { (j) Other circulatory diseases } \\
\text { (k) Accidents, poisoning, violence (to remove unnatural deaths from total mortality) }\end{array}$ & $\begin{array}{c}162,163 \\
151 \\
204 \\
(140-205) \\
-151 \\
-(162,163) \\
-204 \\
501,502 \\
523,001 \\
(470-527) \\
+241 \\
-523 \\
-(501,502) \\
420,422 \\
(330-334) \\
(401-468) \\
-(420,422) \\
(800-999) \\
\\
\text { All causes } \\
\text { less (001) } \\
(140-205) \\
(241) \\
(330-334) \\
(401-468) \\
(470-527) \\
(800-999)\end{array}$ & $\begin{array}{c}162 \\
151 \\
204-207 \\
(140-209) \\
-151 \\
-162 \\
-(204-207) \\
490,491 \\
515,010 \\
(460-519) \\
-515 \\
-(490,491) \\
(410-414) \\
(390-458) \\
-(410-414) \\
\\
(800-999) \\
\\
\text { All causes } \\
\text { less }(010) \\
(140-209) \\
(390-458) \\
(460-519) \\
(800-999)\end{array}$ \\
\hline
\end{tabular}

We are aware of the small defects in the use of the rubrics as given above but found this technique more acceptable than applying the proportions given in the Registrar General's Statistical Review for 1967, Table C.96. 